\title{
Pregnancy, Bovine Somatotropin, and Dietary n-3 Fatty Acids in Lactating Dairy Cows: III. Fatty Acid Distribution
}

\author{
T. R. Bilby, ${ }^{*}$ T. Jenkins, $†$ C. R. Staples, ${ }^{*}$ and W. W. Thatcher ${ }^{1 *}$ \\ *Department of Animal Sciences, University of Florida, Gainesville 32611 \\ †Department of Animal and Veterinary Sciences, Clemson University, SC 29634
}

\begin{abstract}
Our objective was to examine effects of exogenous bovine somatotropin (bST), pregnancy, and dietary fatty acids on fatty acid distribution in various tissues of lactating dairy cows. Two diets were fed, starting about $17 \mathrm{~d}$ in milk (DIM), in which oil of whole cottonseed (control diet) was compared with a calcium salt of fish oil-enriched lipid (FO; $1.9 \%$ of dietary DM). Starting at $44 \pm 5$ DIM, ovulation was synchronized with a presynchronization plus Ovsynch protocol $(\mathrm{d} 0=$ time of synchronized ovulation). Some cows were inseminated (77 $\pm 12 \mathrm{DIM}$ ) to create a pregnant group. On $\mathrm{d}$ 0 and 11 , cows received bST (500 mg) or no bST, and were killed on d 17 (94 \pm 12 DIM). Number of cows in control group was 5 bST-treated cyclic (bST-C), 5 nonbST-treated cyclic (no bST-C), 4 bST-treated pregnant (bST-P), and 5 non-bST-treated pregnant (no bST-P) cows; and for the FO diet: 4 bST-treated (bST-FO-C) and 5 non-bST-treated cyclic (no bST-FO-C) cows. At slaughter, samples of endometrium, liver, muscle, s.c. adipose, internal adipose, and mammary gland were collected. Milk was collected at $75 \pm 5$ DIM. Gas chromatography was used to determine fatty acid percentages in tissues and milk fat. Endometrium from the cows fed FO had increased proportions of C20:5 and C22:6, whereas C20:4 was decreased. Injections of bST reduced both $\mathrm{C} 18: 2$ and the n-6:n-3 ratio, but increased $\mathrm{C} 22: 6$ in endometrium of cyclic control-fed, but not pregnant cows. In addition, FO decreased the n-6:n-3 ratio in all tissues and milk fat except for s.c. and internal adipose tissue. Cows fed FO also had increased C18:3, C20:5, and C22:6 in the liver and mammary tissue, and C18:3 and C22:6 were increased in the milk fat. The FO diet decreased the $\Delta^{9}$-desaturase index [(product of $\Delta^{9}$-desaturase]/(product of $\Delta^{9}$-desaturase + substrate of $\Delta^{9}$-desaturase]; DIX) in muscle and s.c. tissues, accompanied by an increase in saturated fatty acid (SFA) percentage. In addition, FO diet decreased DIX in the
\end{abstract}

Received October 21, 2005.

Accepted May 26, 2006.

${ }^{1}$ Corresponding author: thatcher@animal.ufl.edu endometrium. In mammary and internal adipose tissues, bST increased DIX in cyclic control-fed cows, whereas bST decreased DIX in FO-fed cows, with no difference in the concentration of SFA and UNSFA. Cis9, trans-11 conjugated linoleic acid was increased in milk fat, but decreased in the muscle and s.c. adipose tissue of FO-fed cows. The FO-enriched lipid, bST treatment, and early pregnancy can alter fatty acid percentages and distributions that may alter tissue functionality and functional nutrients of consumer products.

Key words: bovine somatotropin, fatty acids, fish oil, pregnancy

\section{INTRODUCTION}

Some unsaturated fatty acids (UNSFA) have anticarcinogenic effects and other human health-promoting properties (Bauman et al., 2001). Supplementing dietary UNSFA to food-producing animals may increase the concentration of UNSFA in meat and milk, which may be beneficial to human health. In ruminants, biohydrogenation reduces the amount of UNSFA reaching the small intestine for absorption. Protection of UNSFA from ruminal biohydrogenation increases amounts of fatty acids available for absorption in the small intestine.

Feeding fish oil (FO) increased concentrations of the n-3 polyunsaturated fatty acids (PUFA), including $\mathrm{C} 20: 5$ and C22:6, in the milk fat and caruncles, and reduced circulating concentrations of the $\mathrm{PGF}_{2 \alpha}$ metabolite, 13,14-dihydro, 15-keto $\mathrm{PGF}_{2 \alpha}$ in dairy cows (Mattos et al., 2004). Not only can FO increase concentrations of n-3 fatty acids, but it also increased concentrations of conjugated linoleic acid (CLA) in milk fat (Donovan et al., 2000). Both CLA and PUFA, such as C20:5 and C22:6, have been reported to activate peroxisome proliferator-activated receptors (PPAR) that can affect growth hormone receptor expression (Khan and Vanden Heuvel, 2003), prostaglandin production, implantation (Lim et al., 1999), and insulin sensitivity (Berger and Moller, 2002).

Fatty acid composition is diverse among tissues, and certain tissues may preferentially take up particular fatty acids that are functional characteristics for that 
tissue (Abayasekera and Wathes, 1999). Changes in physiological state are accompanied by a homeorhetic response to alter the partitioning of essential nutrients to different organs. Understanding which fatty acids are preferentially sequestered during pregnancy in certain tissues would allow formulation of diets enriched in the fatty acids of interest to replenish depleted fatty acid stores in late lactation and pregnancy to increase partitioning from these tissues during early lactation.

Exogenous bST is used to increase milk production. Bovine somatotropin can alter lipogenesis and lipolysis, thus having dramatic effects on adipose tissue and lipid metabolism (Etherton and Bauman, 1998). Consequently, fatty acid concentration of these tissues and others may be changed; whether the fatty acid profile is altered is unknown.

The objective of this study was to evaluate effects of exogenous bST, pregnancy, and a diet enriched in FO, as well as their interactions, on the distribution and concentration of fatty acids within the endometrium, liver, milk fat, mammary tissue, muscle, s.c. adipose tissue, and internal adipose tissue. Information gained could benefit the management approach to cows during critical biological windows (i.e., transition period, lactogenesis, energy partitioning, and pregnancy) and also be used to provide an improved nutritional product and (or) functional food for consumers.

\section{MATERIALS AND METHODS}

\section{Cows and Experimental Diets}

A more detailed description of cows, management, and collection of samples is provided in a companion article (Bilby et al., 2006b). Briefly, 40 multiparous Holstein cows in late gestation were fed diets formulated to contain $1.51 \mathrm{Mcal}$ of $\mathrm{NE}_{\mathrm{L}} / \mathrm{kg}, 13.1 \% \mathrm{CP}$, and a cationanion difference of $-90 \mathrm{mEq} / \mathrm{kg}$ (DM basis) beginning approximately 3 wk before expected calving. Five cows were excluded from the data analyses for various health concerns. Upon calving, the control diet (no FO) was fed to all cows until 9 DIM. The control diet contained a greater concentration of whole cottonseed but was similar in concentration of ether extract and $\mathrm{NE}_{\mathrm{L}}$ to that containing calcium salt of an FO-enriched lipid product (EnerG-II Reproduction formula, Virtus Nutrition, Fairlawn, OH) as described in Bilby et al. (2006b). From 10 to 16 DIM, 10 cows were assigned to consume an FO diet containing half the final concentration of the FO product $(0.95 \%$ of dietary DM) to adjust the cows to a new fat source. The fatty acid profile of the fat source as given by the manufacturer as $2.2 \% \mathrm{C} 14: 0$, $41 \% \mathrm{C} 16: 0,4.2 \% \mathrm{C} 18: 0,30.9 \% \mathrm{C} 18: 1,0.2 \% \mathrm{C} 18: 1$ trans, 8.0\% C18:2, 0.5\% C18:3, 0.4\% C20:4, 2.0\% C20:5, 2.3\% C22:6, and 2.7\% unknown. Starting at 17 DIM, these cows were switched to the $1.9 \%$ FO-diet and continued on that diet until the end of the study. Cows fed the FO consumed approximately $15 \mathrm{~g} / \mathrm{cow}$ per day of C20:5 and C22:6 combined. Thirty cows remained on the control diet for the duration of the study. Cows were milked thrice daily.

\section{Estrus Synchronization, Ultrasonography of Ovaries, and bST Treatment}

Estrus was synchronized as described in detail by Bilby et al. (2006b). Briefly, cows were presynchronized starting at $44 \pm 5$ DIM (d -27 in relation to day of timed AI) using an injection of $\mathrm{GnRH}$ (86 $\mu \mathrm{g}$ i.m.) followed 7 $\mathrm{d}$ later $(\mathrm{d}-20)$ with an injection of $\mathrm{PGF}_{2 \alpha}(25 \mathrm{mg}$ i.m.). Ten days after the $\mathrm{PGF}_{2 \alpha}$ injection $(\mathrm{d}-10)$, the Ovsynch protocol was initiated using a GnRH injection (86 $\mu \mathrm{g}$ i.m.) followed $7 \mathrm{~d}$ later $(\mathrm{d}-3)$ by an injection of $\mathrm{PGF}_{2 \alpha}$ (25 mg i.m.). At $48 \mathrm{~h}$ after injection of $\mathrm{PGF}_{2 \alpha}, \mathrm{GnRH}$ (86 $\mu \mathrm{g}$ i.m.) was administered (d -1 ), and 16 cows fed the control diet were inseminated $16 \mathrm{~h}$ later. All inseminations were administered by the same technician with semen from 1 Holstein bull of known fertility (Select Sires, Plain City, $\mathrm{OH})$. The cycling group $(\mathrm{n}=19)$ was not inseminated. Inseminated and noninseminated cows received either an injection of bST (500 mg, Posilac; Monsanto Co., St. Louis, MO) or no injection on d 0 (when cows were either inseminated or not) and again on $\mathrm{d} 11$ post-AI. The bST injections were given $11 \mathrm{~d}$ apart instead of $14 \mathrm{~d}$, to allow for a sustained continual exposure to bST until d 17, at which time cows were slaughtered. The bST injections were given s.c. in the space between the ischium and tail head. Three cows with various health concerns, and 2 that underwent CL regression before d 17 were excluded from the study. On d 17 after an induced ovulation, cows $(\mathrm{n}=35)$ were slaughtered to collect tissue samples and verify presence of a conceptus. Pregnancy rates were defined as number of cows classified pregnant based upon visualization of a conceptus in the uterine flushing at slaughter divided by number of cows inseminated. From the inseminated cows that were slaughtered and not pregnant, 6 cows were not treated with bST and 1 cow was treated with bST. These 7 cows were not used for fatty acid analyses. Numbers of cows used for tissue analyses on d 17 for the control diet: 5 bST-treated cyclic (bSTC), 5 non-bST-treated cyclic (no bST-C), 5 bST-treated pregnant (bST-P), and 4 non-bST-treated pregnant (no bST-P) cows; and cyclic cows for the FO diet: 4 bSTtreated (bST-FO-C) and 5 non-bST-treated (no bST-FOC) cows.

\section{Tissue Sample Collection}

For each cow, a sample of milk from the morning (1000 h) milking was collected at $75 \pm 5$ DIM, held at 
$4^{\circ} \mathrm{C}$, and fat was extracted using a detergent solution containing 3\% Triton X-100 (wt/vol) and 7\% sodium hexametaphosphate in distilled water. Milk fat was stored at $-20^{\circ} \mathrm{C}$ until fatty acid analysis.

All cows were killed (94 \pm 12 DIM) in the abattoir of the Animal Sciences Department at the University of Florida. Reproductive tracts were collected within 10 min of slaughter, placed on ice, and taken to the laboratory. The uterine horn ipsilateral to the CL was cut along the mesometrial border, and the endometrium was dissected from the myometrium. Endometrial tissue from the antimesometrial border of the ipsilateral horn was removed, frozen in liquid $\mathrm{N}$, and stored at $-80^{\circ} \mathrm{C}$. Liver, pectoralis profundi muscle, mammary, s.c. adipose adjacent to pectoralis profundi muscle, and internal adipose of perinephric kidney fat were tissues collected at slaughter, immediately placed in liquid $\mathrm{N}$, and stored at $-80^{\circ} \mathrm{C}$. Two sections of approximately 7 $\mathrm{g}$ of each collected tissue were freeze-dried for $24 \mathrm{~h}$ using a lyophilizer (Labconco, Kansas City, MO) to obtain a final mass of approximately $1.5 \mathrm{~g}$ of DM. Fatty acids in dry tissue and milk fat were methylated and separated by gas chromatography as described below.

\section{Milk Fat Isolation and Analyses of Fatty Acid Composition}

Fatty acids in freeze-dried tissue and milk fat samples were converted to methyl esters in $0.5 \mathrm{M}$ sodium methoxide in methanol followed by a second methylation in acetyl chloride:methanol (1:10, vol/vol) based on a procedure described by Kramer et al. (1997) to prevent epimerization and isomerization of conjugated acids.

Methyl esters were separated by GLC (HP 5890, Agilent Technologies, Palo Alto, CA) on a $30 \mathrm{~m} \times 0.25$ $\mathrm{mm} \times 0.2-\mu \mathrm{m}$ film thickness SP2380 capillary column with split (100:1) injection. The temperature program used for the tissue fatty acids was $140^{\circ} \mathrm{C}$ initially (held for $3 \mathrm{~min}$ ), and then raised $3.7^{\circ} \mathrm{C} / \mathrm{min}$ to a final temperature of $220^{\circ} \mathrm{C}$ (held for $20 \mathrm{~min}$ ). Milk fatty acid methyl esters were run using an initial temperature of $50^{\circ} \mathrm{C}$ (held for $2 \mathrm{~min}$ ) and increased $4^{\circ} \mathrm{C} / \mathrm{min}$ to a final temperature of $250^{\circ} \mathrm{C}$ (held for $15 \mathrm{~min}$ ).

Peak identities were done by comparison of retention times to reagent-grade fatty acid standards. Additional structural identification of the C20:3 peak in liver samples was done on an Agilent 5975 gas chromatograph/ mass spectrometer (Agilent Technologies) equipped with a CP Sil 88 column operated at an initial temperature of $120^{\circ} \mathrm{C}$ for $5 \mathrm{~min}$, and increased $2^{\circ} \mathrm{C} / \mathrm{min}$ to a final temperature of $220^{\circ} \mathrm{C}$. Liver peak had a retention time and distinctive ion fragment at 150 that matched a cis-8, cis-11, cis-14 C20:3n-6 methyl ester standard, but did not match retention times or ions at 108 and 192 that were distinctive for the $c i s-5$, cis-8, cis-11 C20:3n-9, or cis-11, cis-14, cis-17 C20:3n-3 methyl ester standards. Geometries of double bonds (cis or trans) were not determined.

Desaturase index (DIX) was used as a proxy for 2 pairs of fatty acids that represent products and substrates for $\Delta^{9}$-desaturase as previously defined [(product of $\Delta^{9}$-desaturase)/(product of $\Delta^{9}$-desaturase + substrate of $\Delta^{9}$-desaturase); Kelsey et al., 2003]. For all tissues except the endometrium, C14:1 was used as the $\Delta^{9}$-desaturase product and $\mathrm{C} 14: 0$ as $\Delta^{9}$-desaturase substrate. In the endometrium, C16:1 was used as the $\Delta^{9}$-desaturase product and $\mathrm{C} 16: 0$ as $\Delta^{9}$-desaturase substrate because C14:1 was undetectable.

\section{Statistical Analyses}

Experimental design was an incomplete factorial design comprising 6 treatments: no bST-C, bST-C, no bstFO-C, bst-FO-C, no bST-P, and bST-P. Proportions of each fatty acid ( $\mathrm{g} / 100 \mathrm{~g}$ of fatty acids) from each tissue source and milk fat were analyzed using the GLM procedure (SAS Inst. Inc., Cary, NC). Mathematical model for milk fat included the main effect of treatment [control (no FO) vs. FO]. Mathematical models for all other tissues included the main effects of treatment [(cyclic (C) vs. pregnant (P), no FO vs. FO, bST vs. no bST), and predesigned orthogonal contrasts were used to compare treatment means. Effects of bST were examined in the cyclic cows fed either control or FO-diets (no bST-C, bST-C, no bST-FO-C, and bST-FO-C) and included a mathematical model of bST, FO, and bST $\times$ FO. The other analytical approach was in cows that were cyclic or pregnant fed the control diet (no bST-C, bST-C, no bST-P, and bST-P) and included a mathematical model of $b S T$, pregnancy status, and bST $\times$ pregnancy status. Because the study had no pregnant cows fed FO, statistical comparisons could not be made between FO-fed cyclic and pregnant cows. Analyses of concentrations of long-chain fatty acids ( $\geq \mathrm{C} 18: 0)$ among all tissue and milk fat sources were analyzed using the GLM procedure of SAS. Mathematical model included the main effect of treatment, tissue source (endometrium, liver, muscle, mammary, s.c. adipose, internal adipose tissue, and milk fat) and treatment $\times$ tissue source. Orthogonal contrasts were used to compare tissue sources as follows: 1) milk fat and mammary tissue vs. endometrium, liver, and muscle; 2) milk fat vs. mammary tissue; 3) endometrium, liver, and muscle vs. s.c. and internal adipose; 4) s.c. vs. internal adipose; 5) endometrium vs. liver and muscle; 6 ) liver vs. muscle.

Fatty acid composition (Tables 1 to 10 ) was analyzed in all tissue sources representing all treatment combi- 
Table 1. Least squares means and pooled SE of the endometrium fatty acid profile (\% of total fatty acids; g/100 g of fatty acids) at d 17 after a synchronized estrus (d 0) in lactating cyclic (C) cows fed a control diet, pregnant $(\mathrm{P})$ cows fed a control diet, and cyclic cows fed a fish oil-enriched lipid (FO) diet and injected with or without bST on d 0 and 11

\begin{tabular}{|c|c|c|c|c|c|c|c|c|c|c|c|c|c|}
\hline Fatty acid & \multicolumn{6}{|c|}{ Treatment $^{1}$} & SE & \multicolumn{3}{|c|}{ Cyclic contrasts $^{2}$} & \multicolumn{3}{|c|}{ Pregnant contrasts ${ }^{2}$} \\
\hline C14:0 & 0.32 & 0.25 & 0.29 & 0.38 & 0.26 & 0.27 & 0.03 & NS & NS & $* *$ & NS & NS & NS \\
\hline C15:0 & 0.30 & 0.30 & 0.41 & 0.42 & 0.27 & 0.28 & 0.04 & $*$ & NS & NS & NS & NS & NS \\
\hline $\mathrm{C} 16: 0$ & 12.57 & 13.00 & 13.40 & 13.77 & 12.33 & 12.81 & 0.34 & $*$ & NS & NS & NS & NS & NS \\
\hline C16:1n-9 & 0.31 & 0.35 & 0.24 & 0.28 & 0.33 & 0.31 & 0.04 & * & NS & NS & NS & NS & NS \\
\hline C18:1 cis-9 & 12.73 & 14.65 & 13.08 & 15.28 & 13.87 & 13.87 & 0.72 & NS & $* *$ & NS & NS & NS & NS \\
\hline C18:2n-6 & 13.61 & 10.94 & 14.54 & 11.99 & 12.64 & 13.46 & 0.81 & NS & $* *$ & NS & NS & NS & $*$ \\
\hline C18:3n-3 & 0.91 & 0.88 & 0.94 & 0.90 & 0.88 & 0.88 & 0.06 & NS & NS & NS & NS & NS & NS \\
\hline CLA $^{3}$ cis -9, trans -11 & 0.19 & 0.17 & 0.15 & 0.21 & 0.20 & 0.13 & 0.03 & NS & NS & NS & NS & NS & NS \\
\hline C20:3n-6 & 3.99 & 3.54 & 3.45 & 3.55 & 3.65 & 3.81 & 0.22 & NS & NS & NS & NS & NS & NS \\
\hline$C 20: 4 n-6$ & 14.81 & 15.85 & 13.55 & 14.00 & 15.00 & 14.50 & 0.51 & $* *$ & NS & NS & NS & NS & NS \\
\hline C20:5n-3 & $<0.01$ & $<0.01$ & 0.10 & 0.15 & $<0.01$ & $<0.01$ & 0.03 & $* *$ & NS & NS & NS & NS & NS \\
\hline
\end{tabular}

${ }^{1}$ No bST-C = Cyclic cows not injected with bST ( $=5$ ); bST-C = cyclic cows injected with bST ( $\mathrm{n}=5$ ); no bST-FO-C = cyclic cows not injected with bST and fed a fish oil-enriched supplement $(\mathrm{n}=5)$; bST-FO-C = cyclic cows injected with bST and fed a fish oil-enriched supplement $(\mathrm{n}=4)$; no bST-P = pregnant cows not injected with bST $(\mathrm{n}=4)$; bST-P = pregnant cows injected with bST $(\mathrm{n}=5)$.

${ }^{2}$ Contrasts for cyclic cows were: FO = (no bST-C + bST-C) vs. (no bST-FO-C + bST-FO-C), bST = (no bST-C + no bST-FO-C) vs. bST-C + bST-FO-C), and bST $\times$ FO interaction $=($ no bST-C + bST FO-C) vs. (bST-C + no bST-FO-C). Contrasts for pregnant cows were: $\mathrm{P}=($ no bST$\mathrm{C}+\mathrm{bST}-\mathrm{C})$ vs. $($ no bST-P + bST-P $), \mathrm{bST}=($ no bST-C + no bST-P $)$ vs. $($ bST-C + bST-P $)$, and bST $\times \mathrm{P}$ interaction $=($ no bST-C + bST-P $)$ vs. (bST-C + no bST-P).

${ }^{3} \mathrm{CLA}=$ Conjugated linoleic acid.

$\dagger P \leq 0.10 ; * P \leq 0.05 ; * * P \leq 0.01 ; \mathrm{NS}=$ nonsignificant.

nations. Responses detected having a $P \leq 0.05$ were considered significant as described in the text.

\section{RESULTS}

\section{Long-Chain Fatty Acid Composition Among Tissues}

Proportions of fatty acid distribution are shown for the endometrium (Table 1), liver (Table 3), mammary (Table 4), milk fat (Table 6), muscle (Table 7), s.c. adipose (Table 9), and internal adipose (Table 10) tissues. Many differences were detected in the proportion of long-chain fatty acids among tissues. For instance, C18:2 concentrations differed $(P<0.01)$ among milk fat, mammary gland, endometrium, liver, and muscle $(3.4,5.4,12.9,12.1$, and $9.6 \pm 0.3 \%$, respectively) with endometrium and liver having the greatest proportion of C18:2. No difference in C18:2 was detected between s.c. and internal adipose tissues (1.97 vs. $2.10 \pm 0.29 \%$, respectively). Proportion of C18:3 differed $(P<0.01)$ among endometrium, liver, and muscle $(0.90,0.41$, and $0.33 \pm 0.01 \%$, respectively) with no difference between milk and mammary gland ( 0.28 vs. $0.28 \pm 0.01 \%$, respectively) and between s.c. and internal adipose ( 0.16 vs. $0.17 \pm 0.01 \%$, respectively) tissues. Proportion of C20:4 differed $(P<0.05)$ among milk fat, mammary gland, endometrium, liver, and muscle $(0.16,0.78,14.62,6.70$, and $3.86 \pm 0.25 \%$, respectively) with the greatest percentage in the endometrium. No difference in C20:4 was detected between the s.c. and internal adipose tissues ( 0.06 vs. $0.04 \pm 0.25 \%$, respectively). Both C20:5 and C22:6 percentages were not different between milk fat and mammary gland $(0.02$ vs. $0.06 \%$ and 0.01 vs. $0.03 \pm 0.02 \%$, respectively). Eicosapentaenoic acid was not detected in the s.c. or internal adipose tissues; however, C22:6 was greater $(P<0.01)$ in internal adipose (0.004 vs. $0.03 \pm 0.02 \%$, respectively). Endometrium, liver, and muscle differed $(P<0.01)$ in both C20:5 $(0.04$, 0.63 , and $0.19 \pm 0.02 \%$, respectively) and C22:6 (1.16, 0.71 , and $0.05 \pm 0.05 \%$, respectively).

An effort was made to detect C20:3n-9 in liver samples because the ratio of C20:3n-9 to C20:4n-6 (>0.4) in tissues has been used in nonruminant species to detect animals in a C18:2-deficiency state (Sewell and McDowell, 1966). Only C20:3n-6, and not C20:3n-9, however, could be detected in liver. Therefore, lactating Holstein cows at approximately 94 DIM in this study were not deficient in C18:2 or this ratio is not applicable to the functioning ruminant or liver may not be a good indicator of C18:2 status.

\section{Fatty Acid Composition in Endometrium at d 17}

Lactating dairy cows had C18:0 as the predominant fatty acid in their endometrium $(\sim 20 \%)$ with 4 fatty 
Table 2. Least squares means and pooled SE for total fatty acids ( $\mathrm{g} / 100 \mathrm{~g}$ of freeze-dried tissue) and different fatty acid percentages ( $\mathrm{g} / 100$ $\mathrm{g}$ of fatty acids) in endometrium and liver tissue at d 17 after a synchronized estrus (d 0) in lactating cyclic (C) cows fed a control diet, pregnant (P) cows fed a control diet, and cyclic cows fed a fish oil-enriched lipid (FO) diet and injected with or without bST on d 0 and 11

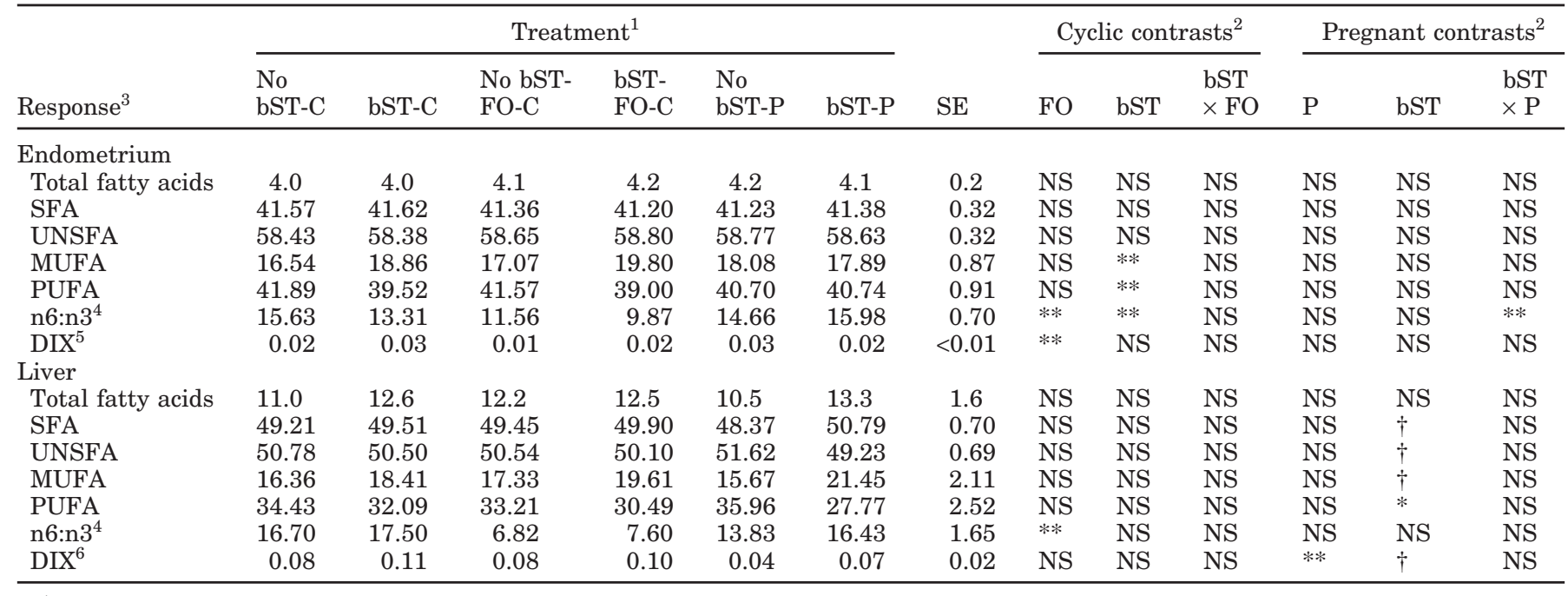

${ }^{1}$ No bST-C = Cyclic cows not injected with bST $(\mathrm{n}=5)$, bST-C = cyclic cows injected with bST $(\mathrm{n}=5)$, no bST-FO-C = cyclic cows not injected with bST and fed a fish oil-enriched supplement $(\mathrm{n}=5)$, bST-FO-C = cyclic cows injected with bST and fed a fish oil-enriched supplement $(\mathrm{n}=4)$, no bST-P = pregnant cows not injected with bST $(\mathrm{n}=4)$, bST-P = pregnant cows injected with bST $(\mathrm{n}=5)$.

${ }^{2}$ Contrasts for cyclic cows were: FO = (no bST-C + bST-C) vs. (no bST-FO-C + bST-FO-C), bST = (no bST-C + no bST-FO-C) vs. bST-C + bST-FO-C), and bST $\times$ FO interaction $=($ no bST-C + bST FO-C) vs. (bST-C + no bST-FO-C). Contrasts for pregnant cows were: $\mathrm{P}=($ no bST$\mathrm{C}+$ bST-C) vs. (no bST-P + bST-P), bST $=($ no bST-C + no bST-P) vs. $($ bST-C + bST-P), and bST $\times$ P interaction $=($ no bST-C + bST-P) vs (bST-C + no bST-P).

${ }^{3} \mathrm{SFA}=$ Saturated fatty acids, UNSFA = unsaturated fatty acids, MUFA = monounsaturated fatty acids, PUFA = polyunsaturated fatty acids.

${ }^{4} \mathrm{n} 6: \mathrm{n} 3=(\mathrm{C} 18: 2+\mathrm{C} 20: 4) /(\mathrm{C} 18: 3+\mathrm{C} 20: 5+\mathrm{C} 22: 6)$

${ }^{5} \mathrm{DIX}=$ Desaturase index $(\mathrm{C} 16: 1) /(\mathrm{C} 16: 0+\mathrm{C} 16: 1)$.

${ }^{6} \mathrm{DIX}=$ Desaturase index $[\mathrm{C} 14: 1 /(\mathrm{C} 14: 0+\mathrm{C} 14: 1)]$.

$\dagger P \leq 0.10 ; * P \leq 0.05 ; * * P \leq 0.01 ; \mathrm{NS}=$ nonsignificant.

acids (C16:0, C18:1, C18:2, and C20:4) of secondary, but similar concentrations (means ranging from 13 to 15\%; Table 1). In endometrial tissue, an interaction was detected $(P \leq 0.01)$ between bST-treated and FO-fed cyclic cows with bST reducing C14:0 in bST-C but increasing C14:0 in bST-FO-C (Table 1). Intake of FO increased proportions of $\mathrm{C} 15: 0(P \leq 0.05), \mathrm{C} 16: 0$ ( $P \leq$ $0.05)$, and $\mathrm{C} 18: 1$-trans but reduced $\mathrm{C} 16: 1(P \leq 0.05)$ and C18:0 ( $P \leq 0.01$; Table 1). Importantly, concentrations of C20:5 and C22:6 were increased $(P \leq 0.01)$ in FO-fed cows with a concurrent decrease $(P \leq 0.01)$ in C20:4 (Table 1). Interestingly, bST treatment increased $(P \leq$ $0.01)$ proportions of $\mathrm{C} 18: 1$ and $\mathrm{C} 22: 6$, but decreased ( $P$ $\leq 0.05$ ) proportion of C18:2 in cyclic cows (Table 1 ). In addition, bST injections decreased $(P \leq 0.05)$ proportion of C18:2 in cyclic control-fed cows but increased it in pregnant cows $(\mathrm{bST} \times$ pregnancy interaction; Table 1$)$. Injections of bST, however, increased $(P \leq 0.05)$ proportion of C22:6 in cyclic control-fed cows, but decreased it in pregnant cows $(\mathrm{bST} \times$ pregnancy interaction; Table 1).

Injection of bST increased $(P \leq 0.01)$ the proportion of monounsaturated fatty acids (MUFA) with a subse- quent decrease $(P \leq 0.01)$ in PUFA (Table 2$)$. The $\mathrm{n}$ 6:n-3 ratio was reduced $(P \leq 0.01)$ due to both FO and bST in cyclic cows. If a conceptus was present, however, cows receiving bST had an increased $(P \leq 0.01) \mathrm{n}-6$ :n3 ratio, whereas it was decreased in those without a conceptus (bST $\times$ pregnancy interaction; Table 2$)$.

\section{Fatty Acid Composition in Liver at d 17}

Stearic acid was the predominant fatty acid identified in liver (19 to $23 \%$ of total) followed by C16:0 (14 to 20\%), C18:1 (12 to 16\%), C18:2 (11 to $13 \%$ ), and C20:3 and C20:4 (4 to 8\%; Table 3). Among control-fed cyclic and pregnant cows, bST increased $(P \leq 0.05)$ the proportion of C14:1 (Table 3) in liver. Feeding FO increased $(P \leq 0.01)$ proportions of $\mathrm{C} 18: 3, \mathrm{C} 20: 5$, and $\mathrm{C} 22: 6$, but decreased $(P \leq 0.05)$ C20:3n-6 (Table 3).

The n-6:n-3 ratio was reduced $(P \leq 0.01)$ when cyclic cows were fed FO (Table 2). Use of bST reduced ( $P$ $\leq 0.05$ ) the concentration of PUFA (Table 2) among pregnant and cyclic control-fed cows. The DIX was decreased $(P \leq 0.01)$ due to pregnancy. 
Table 3. Least squares means and pooled SE of the liver fatty acid profile (\% of total fatty acids; g/100 g of fatty acids) at d 17 after a synchronized estrus (d 0) in lactating cyclic (C) cows fed a control diet, pregnant (P) cows fed a control diet, and cyclic cows fed a fish oilenriched lipid (FO) diet and injected with or without bST on d 0 and 11

\begin{tabular}{|c|c|c|c|c|c|c|c|c|c|c|c|c|c|}
\hline Fatty acid & \multicolumn{6}{|c|}{ Treatment $^{1}$} & SE & \multicolumn{3}{|c|}{ Cyclic contrasts $^{2}$} & \multicolumn{3}{|c|}{ Pregnant contrasts ${ }^{2}$} \\
\hline C14:0 & 1.34 & 1.20 & 1.41 & 1.47 & 1.12 & 1.80 & 0.24 & NS & NS & NS & NS & NS & $\dagger$ \\
\hline C14:1 & 0.12 & 0.14 & 0.13 & 0.14 & 0.05 & 0.13 & 0.02 & NS & NS & NS & $\dagger$ & $*$ & NS \\
\hline C15:0 & 0.25 & 0.24 & 0.26 & 0.26 & 0.21 & 0.35 & 0.05 & NS & NS & NS & NS & NS & NS \\
\hline C16:0 & 15.40 & 16.12 & 16.94 & 19.35 & 13.89 & 19.93 & 1.87 & NS & NS & NS & NS & $\dagger$ & NS \\
\hline C18:1 trans & 1.09 & 1.02 & 1.18 & 1.24 & 1.10 & 1.28 & 0.13 & NS & NS & NS & NS & NS & NS \\
\hline C18:1n-9 & 11.66 & 13.31 & 12.19 & 14.17 & 11.08 & 15.34 & 1.61 & NS & NS & NS & NS & $\dagger$ & NS \\
\hline C18:2n-6 & 12.22 & 11.69 & 12.59 & 12.28 & 12.64 & 10.99 & 0.75 & NS & NS & NS & NS & NS & NS \\
\hline C18:3n-3 & 0.38 & 0.35 & 0.52 & 0.46 & 0.36 & 0.38 & 0.03 & $* *$ & NS & NS & $\mathrm{NS}$ & NS & NS \\
\hline $\mathrm{C} 20: 0$ & 0.54 & 0.54 & 0.54 & 0.58 & 0.69 & 0.71 & 0.11 & NS & NS & NS & NS & NS & NS \\
\hline CLA $^{3}$ cis -9, trans -11 & 0.26 & 0.23 & 0.23 & 0.25 & 0.24 & 0.25 & 0.03 & NS & NS & NS & NS & NS & NS \\
\hline $\mathrm{C} 21: 0$ & 0.17 & 0.22 & 0.14 & 0.06 & 0.18 & 0.15 & 0.02 & $* *$ & NS & $* *$ & NS & NS & $\dagger$ \\
\hline$C 22: 6 n-3$ & 0.65 & 0.17 & 1.34 & 1.22 & 0.75 & 0.11 & 0.29 & $* *$ & NS & NS & NS & $\dagger$ & NS \\
\hline Other & 17.31 & 16.69 & 17.12 & 16.24 & 17.59 & 16.05 & 0.91 & NS & NS & NS & NS & NS & NS \\
\hline
\end{tabular}

${ }^{1}$ No bST-C = Cyclic cows not injected with bST $(\mathrm{n}=5)$; bST-C = cyclic cows injected with bST $(\mathrm{n}=5)$; no bST-FO-C = cyclic cows not injected with bST and fed a fish oil-enriched supplement $(\mathrm{n}=5)$; bST-FO-C = cyclic cows injected with bST and fed a fish oil-enriched supplement $(\mathrm{n}=4)$; no bST-P = pregnant cows not injected with bST $(\mathrm{n}=4)$; bST-P = pregnant cows injected with bST $(\mathrm{n}=5)$.

${ }^{2}$ Contrasts for cyclic cows were: FO = (no bST-C + bST-C) vs. (no bST-FO-C + bST-FO-C), bST = (no bST-C + no bST-FO-C) vs. bST-C + bST-FO-C), and bST $\times$ FO interaction $=($ no bST-C + bST FO-C $)$ vs. $($ bST-C + no bST-FO-C $)$. Contrasts for pregnant cows were: $\mathrm{P}=($ no bST$\mathrm{C}+$ bST-C) vs. $($ no bST-P + bST-P), bST $=($ no bST-C + no bST-P) vs. $($ bST-C + bST-P $)$, and bST $\times$ P interaction $=($ no bST-C + bST-P) vs. (bST-C + no bST-P).

${ }^{3} \mathrm{CLA}=$ Conjugated linoleic acid

$\dagger P \leq 0.10 ; * P \leq 0.05 ; * * P \leq 0.01$; NS = nonsignificant.

\section{Fatty Acid Composition in Mammary Tissue at $d 17$}

Palmitic (27\%) and C18:1 (25\%) were the predominant fatty acids identified in mammary tissue followed by $\mathrm{C} 18: 0$ (17\%) and $\mathrm{C} 14: 0$ and $\mathrm{C} 18: 2$ (5 to 6\%; Table 4). In mammary tissue, feeding FO decreased $(P \leq 0.10)$ the proportion of $\mathrm{C} 14: 1$, but increased $(P \leq 0.05)$ the proportions of C18:3; C20:0; C20:5; and C22:6 (Table 4). Using bST decreased $(P \leq 0.01) \mathrm{C} 18: 3$ in cyclic cows fed FO or cottonseeds but increased $(P \leq 0.05)$ C16:1 within pregnant and cyclic cows fed the control diet (Table 4).

Feeding FO decreased $(P \leq 0.01)$ dramatically the n6:n-3 ratio (Table 5). Between cyclic FO and controlfed cows, bST injection increased $(P \leq 0.05)$ DIX in control-fed cows, but reduced the DIX in FO-fed cows $(\mathrm{bST} \times$ FO interaction; Table 5).

\section{Fatty Acid Composition in Milk Collected Between 70 and 80 DIM}

Feeding FO increased $(P \leq 0.01) \mathrm{C} 4: 0$; C16:0; C18:3; cis-9, trans-11 CLA; and C22:6 but decreased $(P \leq 0.05)$
C18:0 and C20:3 (Table 6). The FO diet decreased ( $P \leq$ 0.01 ) the $n-6: n-3$ ratio (Table 6 ).

\section{Fatty Acid Composition in Muscle at d 17}

Oleic acid was the predominant fatty acid identified in muscle (28 to 33\%) followed by C16:0 (22 to $25 \%$ ), C18:0 (17 to 20\%), and C18:2 (9 to 13\%; Table 7). Feeding FO decreased $(P \leq 0.05) \mathrm{C} 14: 1 ;$ cis-11 C18:1; and cis-9, trans-11 CLA (Table 7). Both the FO diet and pregnancy increased $(P \leq 0.05)$ the proportion of SFA with a subsequent decrease $(P \leq 0.05)$ in UNSFA when compared with cyclic control-fed cows (Table 8). The FO diet decreased $(P \leq 0.01)$ both the n-6:n-3 ratio and the DIX (Table 8 ). In addition, pregnancy decreased ( $P$ $\leq 0.01$ ) the DIX (Table 8).

\section{Fatty Acid Composition in s.c. Adipose Tissue at $d 17$}

Oleic acid was the predominant fatty acid identified in s.c. adipose tissue (29 to 37\%) followed by C16:0 (25 to $29 \%$ ), C18:0 (15 to $25 \%$ ), and others ( $<5 \%$; Table 9 ). 
Table 4. Least squares means and pooled SE for the mammary tissue fatty acid profile (\% of total fatty acids; g/100 g of fatty acids) at d 17 after a synchronized estrus (d 0) in lactating cyclic (C) cows fed a control diet, pregnant $(\mathrm{P})$ cows fed a control diet, and cyclic cows fed a fish oil-enriched lipid (FO) diet and injected with or without bST on d 0 and 11

\begin{tabular}{|c|c|c|c|c|c|c|c|c|c|c|c|c|c|}
\hline \multirow[b]{2}{*}{ Fatty acid } & \multicolumn{6}{|c|}{ Treatment $^{1}$} & \multirow[b]{2}{*}{$\mathrm{SE}$} & \multicolumn{3}{|c|}{ Cyclic contrasts $^{2}$} & \multicolumn{3}{|c|}{ Pregnant contrasts ${ }^{2}$} \\
\hline & $\begin{array}{l}\text { No } \\
\text { bST-C }\end{array}$ & bST-C & $\begin{array}{l}\text { No bST- } \\
\text { FO-C }\end{array}$ & $\begin{array}{l}\text { bST- } \\
\text { FO-C }\end{array}$ & $\begin{array}{l}\text { No } \\
\text { bST-P }\end{array}$ & bST-P & & FO & bST & $\begin{array}{l}\mathrm{bST} \\
\times \mathrm{FO}\end{array}$ & $\mathrm{P}$ & bST & $\begin{array}{l}b S T \\
\times P\end{array}$ \\
\hline C10:0 & 1.38 & 1.27 & 1.26 & 1.21 & 1.64 & 1.55 & 0.25 & NS & NS & NS & NS & NS & NS \\
\hline C11:0 & 0.11 & 0.11 & 0.10 & 0.08 & 0.08 & 0.11 & 0.02 & NS & NS & NS & NS & NS & NS \\
\hline C12:0 & 1.71 & 1.48 & 1.42 & 1.40 & 1.99 & 1.78 & 0.27 & NS & NS & NS & NS & NS & NS \\
\hline C14:0 & 6.44 & 5.51 & 5.56 & 5.16 & 6.79 & 6.08 & 0.62 & NS & NS & NS & NS & NS & NS \\
\hline C16:0 & 26.72 & 26.38 & 27.09 & 27.76 & 26.51 & 25.60 & 0.61 & NS & NS & NS & NS & NS & NS \\
\hline C16:1n-9 & 0.96 & 1.42 & 1.12 & 1.17 & 1.09 & 1.17 & 0.14 & NS & $\dagger$ & NS & NS & $*$ & NS \\
\hline C18:0 & 17.31 & 16.88 & 16.08 & 16.40 & 16.78 & 17.43 & 0.98 & $\mathrm{NS}$ & NS & NS & NS & NS & NS \\
\hline C18:1 trans & 2.92 & 2.32 & 2.97 & 2.77 & 3.10 & 2.77 & 0.30 & NS & NS & NS & NS & NS & NS \\
\hline C18:1 & 23.79 & 27.27 & 24.76 & 26.26 & 24.10 & 25.49 & 1.45 & NS & $\dagger$ & NS & NS & NS & NS \\
\hline C18:1 cis-11 & 1.10 & 1.05 & 1.01 & 1.00 & 1.02 & 1.11 & 0.09 & NS & NS & NS & NS & NS & NS \\
\hline C18:2n-6 & 5.66 & 4.97 & 6.02 & 5.35 & 5.33 & 5.13 & 0.40 & NS & NS & NS & NS & $\dagger$ & NS \\
\hline $\mathrm{C} 21: 0$ & 0.01 & 0.01 & 0.02 & 0.00 & 0.02 & 0.02 & $<0.01$ & NS & NS & NS & NS & NS & NS \\
\hline C20:3n-6 & 0.46 & 0.45 & 0.46 & 0.39 & 0.39 & 0.43 & 0.04 & NS & NS & NS & NS & NS & NS \\
\hline C20:4n-6 & 0.76 & 0.84 & 0.81 & 0.77 & 0.71 & 0.77 & 0.12 & NS & NS & NS & NS & NS & NS \\
\hline C22:0 & 0.06 & 0.06 & 0.08 & 0.07 & 0.06 & 0.05 & 0.01 & $\dagger$ & NS & NS & NS & NS & NS \\
\hline C20:5n-3 & 0.05 & 0.04 & 0.09 & 0.08 & 0.04 & 0.04 & 0.01 & $* *$ & NS & NS & NS & NS & NS \\
\hline C22:6n-3 & 0.03 & 0.00 & 0.07 & 0.05 & 0.00 & 0.00 & 0.02 & $* *$ & NS & NS & NS & NS & NS \\
\hline C24:0 & 0.03 & 0.03 & 0.03 & 0.03 & 0.04 & 0.02 & $<0.01$ & NS & NS & NS & NS & NS & NS \\
\hline Other & 7.86 & 7.56 & 8.34 & 7.60 & 7.67 & 7.71 & 0.35 & NS & NS & NS & NS & NS & NS \\
\hline
\end{tabular}

${ }^{1}$ No bST-C = Cyclic cows not injected with bST $(\mathrm{n}=5)$; bST-C = cyclic cows injected with bST $(\mathrm{n}=5)$; no bST-FO-C = cyclic cows not injected with bST and fed a fish oil-enriched supplement $(\mathrm{n}=5)$; bST-FO-C = cyclic cows injected with bST and fed a fish oil-enriched supplement $(\mathrm{n}=4)$; no bST-P = pregnant cows not injected with bST $(\mathrm{n}=4)$; bST-P = pregnant cows injected with bST $(\mathrm{n}=5)$.

${ }^{2}$ Contrasts for cyclic cows were: FO = (no bST-C + bST-C) vs. (no bST-FO-C + bST-FO-C), bST = (no bST-C + no bST-FO-C) vs. bST-C + bST-FO-C), and bST $\times$ FO interaction $=($ no bST-C + bST FO-C $)$ vs. $($ bST-C + no bST-FO-C $)$. Contrasts for pregnant cows were: $\mathrm{P}=($ no bST$\mathrm{C}+\mathrm{bST}-\mathrm{C})$ vs. $($ no bST-P + bST-P $), \mathrm{bST}=($ no bST-C + no bST-P) vs. $(\mathrm{bST}-\mathrm{C}+\mathrm{bST}-\mathrm{P})$, and bST $\times \mathrm{P}$ interaction $=($ no bST-C $+\mathrm{bST}-\mathrm{P})$ vs. (bST-C + no bST-P).

${ }^{3} \mathrm{CLA}=$ Conjugated linoleic acid.

$\dagger P \leq 0.10 ; * P \leq 0.05 ; * * P \leq 0.01 ; \mathrm{NS}=$ nonsignificant.

In s.c. adipose tissue, feeding $\mathrm{FO}$ increased $(P \leq 0.05)$ proportions of $\mathrm{C} 16: 0$ and $\mathrm{C} 18: 0$ but decreased $(P \leq 0.05)$ C18:1 and cis-9, trans-11 CLA (Table 9). Also, bST increased $(P \leq 0.05) \mathrm{C} 16: 0$ among FO and control-fed cyclic cows (Table 9). The FO diet alone decreased ( $P \leq$ $0.05)$ trans -9 , trans-11 CLA and when bST was injected, proportion of trans-9, trans-11 CLA was increased ( $P \leq$ 0.05 ) back to the same concentration as control-fed cows (bST $\times$ FO interaction; Table 9). The C20:5 was undetectable and $\mathrm{C} 22: 6$ was barely detectable.

The FO diet increased $(P \leq 0.01)$ SFA and decreased UNSFA and MUFA when compared with cyclic controlfed cows (Table 8). Also, FO decreased $(P \leq 0.05)$ the DIX within cyclic cows.

\section{Fatty Acid Composition in Internal Adipose Tissue at d 17}

Stearic acid was the predominant fatty acid identified in internal adipose tissue (31 to 34\%) followed by C18:1 and C16:0 (24 to 28\%); others were $\leq 3 \%$ (Table 10). In internal adipose tissue, the $\mathrm{FO}$ increased $(P \leq 0.05)$ proportions of $\mathrm{C} 15: 0$, but reduced proportions of $\mathrm{C} 22: 6$ (Table 10). Use of bST increased $(P \leq 0.01)$ proportions of C14:1 in cyclic control-fed cows but reduced concentrations in FO-fed cyclic cows (Table 10).

Using bST increased $(P \leq 0.05)$ the $\mathrm{n}-6: \mathrm{n}-3$ ratio in internal adipose tissue of pregnant cows but decreased the ratio in cyclic cows (bST $\times$ pregnant interaction; Table 8$)$. In addition, bST injections increased $(P \leq 0.01)$ the DIX in cyclic control-fed cows with no change in FO-fed cows $(\mathrm{FO} \times \mathrm{bST}$ interaction; Table 8$)$. The same interaction occurred for pregnant and cyclic control-fed cows with bST increasing $(P \leq 0.05)$ the DIX in cyclic cows with no effect in pregnant cows (Table 8).

\section{DISCUSSION}

Fatty acid profiles detected in the current study compare favorably with those cited by others for bovine 
Table 5. Least squares means and pooled SE for total fatty acids ( $\mathrm{g} / 100 \mathrm{~g}$ of freeze-dried tissue) and different fatty acid percentages (g/100 $\mathrm{g}$ of fatty acids) in mammary tissue. Mammary tissue was collected at d 17 after a synchronized estrus (d 0) in cyclic (C) and pregnant (P) cows fed a control or fish oil (FO) diet, and injected with or without bST on d 0 and 11

\begin{tabular}{|c|c|c|c|c|c|c|c|c|c|c|c|c|c|}
\hline \multirow[b]{2}{*}{ Response $^{3}$} & \multicolumn{6}{|c|}{ Treatment $^{1}$} & \multirow[b]{2}{*}{$\mathrm{SE}$} & \multicolumn{3}{|c|}{ Cyclic contrasts $^{2}$} & \multicolumn{3}{|c|}{ Pregnant contrasts ${ }^{2}$} \\
\hline & $\begin{array}{l}\text { No } \\
\text { bST-C }\end{array}$ & bST-C & $\begin{array}{l}\text { No bST- } \\
\text { FO-C }\end{array}$ & $\begin{array}{l}\text { bST- } \\
\text { FO-C }\end{array}$ & $\begin{array}{l}\text { No } \\
\text { bST-P }\end{array}$ & bST-P & & $\mathrm{FO}$ & bST & $\begin{array}{l}\mathrm{bST} \\
\times \mathrm{FO}\end{array}$ & $\mathrm{P}$ & bST & $\begin{array}{l}\mathrm{bST} \\
\times \mathrm{P}\end{array}$ \\
\hline SFA & 59.91 & 57.29 & 57.90 & 57.74 & 59.58 & 58.78 & 1.77 & NS & NS & NS & NS & NS & NS \\
\hline UNSFA & 40.09 & 42.70 & 42.11 & 42.26 & 40.42 & 41.22 & 1.77 & NS & NS & NS & NS & NS & NS \\
\hline MUFA & 31.65 & 35.12 & 32.97 & 33.66 & 32.88 & 33.48 & 1.71 & NS & NS & NS & NS & NS & NS \\
\hline PUFA & 8.44 & 7.59 & 9.13 & 8.60 & 7.55 & 7.74 & 0.61 & NS & NS & NS & NS & NS & NS \\
\hline
\end{tabular}

${ }^{1}$ No bST-C = Cyclic cows not injected with bST $(\mathrm{n}=5)$; bST-C = cyclic cows injected with bST ( $\mathrm{n}=5$ ); no bST-FO-C = cyclic cows not injected with bST and fed a fish oil-enriched supplement $(\mathrm{n}=5)$; bST-FO-C = cyclic cows injected with bST and fed a fish oil-enriched supplement $(\mathrm{n}=4)$; no bST-P = pregnant cows not injected with bST $(\mathrm{n}=4)$; bST-P = pregnant cows injected with bST $(\mathrm{n}=5)$.

${ }^{2}$ Contrasts for cyclic cows were: $\mathrm{FO}=($ no bST-C + bST-C) vs. (no bST-FO-C + bST-FO-C), bST = (no bST-C + no bST-FO-C) vs. bST-C + bST-FO-C $)$, and bST $\times$ FO interaction $=($ no bST-C + bST FO-C $)$ vs. $($ bST-C + no bST-FO-C $)$. Contrasts for pregnant cows were: $\mathrm{P}=($ no bST$\mathrm{C}+$ bST-C) vs. $($ no bST-P + bST-P), bST $=($ no bST-C + no bST-P) vs. $($ bST-C + bST-P), and bST $\times$ P interaction $=($ no bST-C + bST-P $)$ vs. (bST-C + no bST-P).

${ }^{3} \mathrm{SFA}=$ Saturated fatty acids, UNSFA = unsaturated fatty acids, MUFA = monounsaturated fatty acids, PUFA = polyunsaturated fatty acids, DIX = desaturase index $(\mathrm{C} 14: 1) /(\mathrm{C} 14: 0+\mathrm{C} 14: 1)), \mathrm{n} 6: \mathrm{n} 3=(\mathrm{C} 18: 2+\mathrm{C} 20: 4) /(\mathrm{C} 18: 3+\mathrm{C} 20: 5+\mathrm{C} 20: 6)$.

$\dagger P \leq 0.10 ; * P \leq 0.05$; ** $P \leq 0.01$; NS = nonsignificant.

tissues. Endometrium of nonlactating mature Angus cows had C18:0 and C18:1 (14 to 16\%) as the predominant fatty acids, whereas C16:0, C18:2, and C20:4 were of secondary proportion and similar to one another $(10$ to $12 \%$; Burns et al., 2003). Liver of cows in the current study contained similar concentrations of fatty acids to those reported by Rukkwamsuk et al. (1999) for lactating cows biopsied at $6 \mathrm{wk}$ of lactation. Authors were unable to find published fatty acid profiles of mammary gland tissue from lactating dairy cows. Fatty acid profile of mammary stroma of 12-mo-old Holstein heifers, however, was approximately $3 \% \mathrm{C} 14: 0,29 \% \mathrm{C} 16: 0,3 \%$ C16:1, 22\% C18:0, 35\% C18:1 cis, $4 \%$ C18:1 trans, $1 \%$ C18:2, 1\% C18:3, and 0.02\% C20:4 (Thibault et al., 2003). Mammary tissue from lactating cows in the present study had a greater concentration of C14:0 (6\%) and C18:2 (6\%) but less C18:1 (27\%). Proportions of muscle fatty acids from lactating Holstein cows in the current study were similar to those reported by Andrae et al. (2001) for feedlot steers graded as standard, except that proportion of C18:1 was greater (40\%) and that of C18:2 was less (5\%) for the steers. Proportions of fatty acids in s.c. adipose tissue were similar to those in the perianal region of lactating dairy cows reported by Rukkwamsuk et al. (2000). The perinephric (internal) fat of feedlot steers (573 kg of BW) at slaughter contained $2 \% \mathrm{C} 14: 0,25 \% \mathrm{C} 16: 0,1 \% \mathrm{C} 16: 1,31 \% \mathrm{C} 18: 0,35 \%$ C18:1, 2\% C18:2, and 0.1\% C18:3 (Felton and Kerley, 2004), which matches up closely with the fatty acid profile of the internal fat of lactating Holstein cows in this study, although C18:1 was somewhat greater in the steers.
Cows fed FO had an increased proportion of C20:5 and C22:6 in the endometrium (Table 1), liver (Table 2 ), and mammary tissue (Table 4 ), and C22:6 was increased in the milk fat (Table 6) compared with cows not fed FO. However, proportions of C20:5 and C22:6 were not increased in s.c. and internal adipose tissues. Feeding fish oil at $4.3 \%$ of dietary DM increased the concentrations of $\mathrm{C} 20: 5$ from 0.04 to $0.29 \%$ and of $\mathrm{C} 22: 6$ from 0.01 to $0.32 \%$ in subcutaneous adipose tissue of 40-kg lambs (Cooper et al., 2004). We did not detect an increase in C20:5 and C22:6 in subcutaneous tissue in the current study, probably because we fed much less FO. The fatty acid profile of mammary tissue also is susceptible to influence by changing dietary fats. By including soybean oil in the concentrate $(20 \%)$, the concentration of C18:0 increased from 22 to $25 \%$, of C18:2 increased from 1 to $2 \%$, and of C18:1 trans increased from 4 to $9 \%$ in mammary gland stroma of 12 -mo-old Holstein heifers (Thibault et al., 2003). This change was concurrent with a decrease in C16:0 from 29 to $26 \%$ and in C18:1 from 34 to $29 \%$.

Once absorbed from the digestive tract, these differences in C20:5 and C22:6 concentrations may reflect differences in fatty acid turnover among the tissues. Within the endometrium, concentrations of C20:5 and C22:6 were increased whereas that of $\mathrm{C} 20: 4$ was decreased. Consequently, slightly less C20:4 would be available for $\mathrm{PGF}_{2 \alpha}$ production and other products of the PG2 series, thereby potentially reducing secretion of $\mathrm{PGF}_{2 \alpha}$. Endometrial $\mathrm{PGF}_{2 \alpha}$ can cause corpus luteum (CL) regression by binding to receptors on the CL and inducing luteal oxytocin secretion. This coordinates a 
Table 6. Least squares means and pooled SE for the milk fatty acid profile (\% of total fatty acids; $\mathrm{g} / 100 \mathrm{~g}$ of fatty acids) and different fatty acid percentages collected between 70 to 80 DIM in lactating cyclic cows fed a diet containing whole cottonseed (WCS) or a fish oil-enriched (FO) supplement

\begin{tabular}{|c|c|c|c|c|}
\hline \multirow[b]{2}{*}{ Fatty acid $^{1}$} & \multicolumn{2}{|c|}{ Treatment $^{2}$} & \multirow[b]{2}{*}{ SE } & \multirow[b]{2}{*}{ Contrast } \\
\hline & WCS & FO & & \\
\hline C4:0 & 4.36 & 4.98 & 0.16 & $* *$ \\
\hline C6:0 & 1.98 & 2.06 & 0.10 & NS \\
\hline C8:0 & 0.78 & 0.73 & 0.07 & NS \\
\hline C10:0 & 2.36 & 1.98 & 0.20 & NS \\
\hline C12:0 & 2.80 & 2.33 & 0.21 & NS \\
\hline C14:0 & 9.49 & 9.28 & 0.33 & NS \\
\hline C14:1 & 0.92 & 0.89 & 0.06 & NS \\
\hline C15:0 & 0.84 & 0.72 & 0.08 & NS \\
\hline C16:0 & 28.08 & 32.45 & 0.54 & $* *$ \\
\hline C16:1n-9 & 1.22 & 1.41 & 0.06 & $\dagger$ \\
\hline C17:0 & 0.46 & 0.43 & 0.02 & NS \\
\hline C18:0 & 14.26 & 10.94 & 0.77 & $* *$ \\
\hline C18:1 trans & 3.54 & 3.61 & 0.46 & NS \\
\hline C18:1n-9 & 18.92 & 18.46 & 0.65 & NS \\
\hline C18:2n-6 & 3.40 & 3.42 & 0.13 & NS \\
\hline C18:3n-3 & 0.26 & 0.33 & 0.01 & $* *$ \\
\hline C20:0 & 0.16 & 0.17 & 0.01 & NS \\
\hline CLA cis-9, trans-11 & 0.41 & 0.53 & 0.04 & $*$ \\
\hline CLA cis-12, trans-10 & 0.01 & 0.01 & $<0.01$ & NS \\
\hline CLA trans -9, trans -11 & 0.06 & 0.08 & 0.01 & NS \\
\hline $\mathrm{C} 20: 3 \mathrm{n}-6$ & 0.16 & 0.11 & 0.02 & * \\
\hline C20:4n-6 & 0.16 & 0.13 & 0.01 & NS \\
\hline C21:0 & 0.02 & 0.01 & $<0.01$ & NS \\
\hline C22:0 & 0.01 & 0.03 & $<0.01$ & NS \\
\hline C20:5n-3 & 0.02 & 0.02 & $<0.01$ & NS \\
\hline C22:6n-3 & 0.00 & 0.02 & $<0.01$ & $* *$ \\
\hline C24:0 & 0.01 & 0.01 & $<0.01$ & NS \\
\hline Other & 5.30 & 4.88 & 0.23 & NS \\
\hline \multicolumn{5}{|c|}{ Milk fat fatty acid percentages } \\
\hline SFA & 70.91 & 70.98 & 1.04 & NS \\
\hline UNSFA & 29.09 & 29.02 & 0.88 & NS \\
\hline MUFA & 24.62 & 24.37 & 0.81 & NS \\
\hline PUFA & 4.48 & 4.65 & 0.16 & NS \\
\hline n6:n3 & 13.00 & 9.58 & 0.37 & $* *$ \\
\hline DIX & 0.09 & 0.09 & $<0.01$ & NS \\
\hline
\end{tabular}

${ }^{1} \mathrm{CLA}=$ Conjugated linoleic acid; $\mathrm{SFA}=$ saturated fatty acids, UNSFA = unsaturated fatty acids, MUFA = monounsaturated fatty acids, PUFA = polyunsaturated fatty acids, DIX = desaturase index $[$ C14:1 $) /($ C14:0 $+\mathrm{C} 14: 1)], \mathrm{n} 6: \mathrm{n} 3=(\mathrm{C} 18: 2+\mathrm{C} 20: 4) /(\mathrm{C} 18: 3+\mathrm{C} 20: 5+\mathrm{C} 20: 6)$

${ }^{2} \mathrm{WCS}=$ Whole-cottonseed-fed cows $(\mathrm{n}=12) ; \mathrm{FO}=$ fish oil-fed cows $(\mathrm{n}=5)$

$\dagger P \leq 0.10 ; * P \leq 0.05 ; * * P \leq 0.01 ; \mathrm{NS}=$ nonsignificant.

positive feedback loop ultimately causing CL regression. Reduced endometrial secretion of $\mathrm{PGF}_{2 \alpha}$ would maintain the CL and possibly pregnancy. Burns et al. (2003) reported an increase in C20:5 with a decrease in C20:4 in caruncular endometrial tissue on $d 18$ postestrus from beef cows fed fish meal. In addition, Mattos et al. (2004) reported an increase in C20:5 and C22:6 in caruncular tissue at parturition in Holstein cows fed fish oil vs. olive oil. Further, in the present study, incorporation of these fatty acids into the endometrium resulted in differential effects on gene and protein expression of enzymes involved in the prostaglandin cascade regardless of bST injection (Bilby et al., 2006a). Injections of bST reduced $\mathrm{C} 18: 2$ and the $n-6: n-3$ ratio and increased $\mathrm{C} 22: 6$ in the endometrium of the cyclic cows but not in pregnant cows. It is possible that the secretions from the growing conceptus can alter the uterine responsiveness to bST injections. Ratio of $n-$ 6:n-3 was reduced by FO in milk fat and tissues, except for s.c. and internal adipose tissue.

Similar to endometrial tissue, the FO diet also increased C18:3, C20:5, and C22:6 in the liver. These PUFA are ligands for PPAR, which are nuclear transcription factors that can affect gene transcription (Berger and Moller, 2002). The PPAR $\alpha$ decreased expression of growth hormone (GH)-activated genes in rat liver (Corton et al., 1998). The "cross-talk" between the PPAR isomers and GH may reduce the IGF-I response to exogenous bST injections in FO-fed cows, as reported by Bilby et al. (2006b). Importantly, in the endome- 
Table 7. Least squares means and pooled SE for the muscle fatty acid profile (\% of total fatty acids; g/100 g of fatty acids) at d 17 after a synchronized estrus $(\mathrm{d}$ 0) in lactating cyclic $(\mathrm{C})$ cows fed a control diet, pregnant $(\mathrm{P})$ cows fed a control diet, and cyclic cows fed a fish oilenriched lipid (FO) diet and injected with or without bST on d 0 and 11

\begin{tabular}{|c|c|c|c|c|c|c|c|c|c|c|c|c|c|}
\hline Fatty acid & \multicolumn{6}{|c|}{ Treatment $^{1}$} & $\mathrm{SE}$ & \multicolumn{3}{|c|}{ Cyclic contrasts $^{2}$} & \multicolumn{3}{|c|}{ Pregnant contrasts ${ }^{2}$} \\
\hline C14:0 & 1.95 & 1.75 & 1.76 & 1.91 & 2.20 & 2.20 & 0.31 & NS & NS & NS & NS & NS & NS \\
\hline C14:1 & 0.43 & 0.47 & 0.21 & 0.21 & 0.33 & 0.38 & 0.08 & $* *$ & NS & NS & NS & NS & NS \\
\hline C15:0 & 0.24 & 0.23 & 0.27 & 0.27 & 0.28 & 0.27 & 0.04 & NS & NS & NS & NS & NS & NS \\
\hline C16:0 & 23.50 & 22.25 & 23.89 & 23.84 & 23.79 & 24.78 & 1.17 & NS & NS & NS & NS & NS & NS \\
\hline C18:1 trans & 1.79 & 1.49 & 1.66 & 1.90 & 1.87 & 1.70 & 0.22 & NS & NS & NS & NS & NS & NS \\
\hline C18:1 cis-9 & 33.13 & 31.32 & 28.18 & 27.73 & 32.07 & 32.71 & 2.70 & NS & NS & NS & NS & NS & NS \\
\hline C18:1 cis-11 & 1.83 & 1.85 & 1.45 & 1.51 & 1.64 & 1.58 & 0.16 & $*$ & NS & NS & NS & NS & NS \\
\hline C18:2n-6 & 10.86 & 12.06 & 13.06 & 12.16 & 9.74 & 8.86 & 1.93 & NS & NS & NS & NS & NS & NS \\
\hline C18:3n-3 & 0.36 & 0.39 & 0.44 & 0.44 & 0.33 & 0.34 & 0.04 & NS & NS & NS & NS & NS & NS \\
\hline $\mathrm{C} 20: 0$ & 0.13 & 0.15 & 0.09 & 0.17 & 0.14 & 0.09 & 0.03 & NS & NS & NS & NS & NS & NS \\
\hline CLA $^{3}$ cis -9, trans -11 & 0.31 & 0.29 & 0.20 & 0.23 & 0.28 & 0.21 & 0.04 & $* *$ & NS & NS & NS & NS & NS \\
\hline C22:6n-3 & 0.15 & 0.25 & 0.29 & 0.28 & 0.17 & 0.19 & 0.08 & NS & NS & NS & NS & $\dagger$ & NS \\
\hline Other & 0.00 & 0.00 & 0.17 & 0.17 & 0.04 & 0.00 & 0.03 & NS & NS & NS & NS & NS & NS \\
\hline
\end{tabular}

${ }^{1}$ No bST-C = Cyclic cows not injected with bST $(\mathrm{n}=5)$; bST-C = cyclic cows injected with bST $(\mathrm{n}=5)$; no bST-FO-C = cyclic cows not injected with bST and fed a fish oil-enriched supplement $(\mathrm{n}=5)$; bST-FO-C = cyclic cows injected with bST and fed a fish oil-enriched supplement $(\mathrm{n}=4)$; no bST-P = pregnant cows not injected with bST $(\mathrm{n}=4)$; bST-P = pregnant cows injected with bST $(\mathrm{n}=5)$.

${ }^{2}$ Contrasts for cyclic cows were: FO = (no bST-C + bST-C) vs. (no bST-FO-C + bST-FO-C), bST = (no bST-C + no bST-FO-C) vs. bST-C + bST-FO-C), and bST $\times$ FO interaction $=($ no bST-C + bST FO-C $)$ vs. $($ bST-C + no bST-FO-C $)$. Contrasts for pregnant cows were: $\mathrm{P}=($ no bST$\mathrm{C}+$ bST-C) vs. $($ no bST-P + bST-P), bST $=($ no bST-C + no bST-P) vs. $($ bST-C + bST-P $)$, and bST $\times$ P interaction $=($ no bST-C + bST-P) vs. (bST-C + no bST-P).

${ }^{3} \mathrm{CLA}=$ Conjugated linoleic acid

$\dagger P \leq 0.10 ; * P \leq 0.05 ; * * P \leq 0.01$; NS = nonsignificant.

trium, PPAR $\delta$ is vital for normal fertility, serving as a regulator of prostaglandin production and vital to embryo implantation in rodent models (Lim et al., 1999). The PPAR seem to be one possible route by which PUFA can have beneficial effects in humans through regulation of atherosclerotic plaque formation and stability, vascular tone, angiogenesis, antiinflammatory activity, cellular differentiation, and anticarcinogenic (Berger and Moller, 2002).

Proportions of fatty acids were different among tissue sources. Milk fat and mammary tissue seemed to be similar in several fatty acids such as C18:3, C20:5, and C22:6. This could be due to the amount of milk still in the mammary tissue cells. Also, s.c. and internal adipose tissues were similar for several long-chain fatty acids. Although there are some tissues that are similar, a wide variation exists in proportions of PUFA, MUFA, and SFA across all tissues. These large tissue differences in proportions of fatty acids could be an indication of the particular fatty acid(s) needed for proper tissue functionality.

Stearoyl-CoA desaturase enzyme, also known as $\Delta^{9}$ desaturase, is responsible for the oxidation reaction converting SFA to MUFA by the addition of a cis double bond between carbons 9 and 10 of some medium- and long-chain fatty acids (Tocher et al., 1998) and also can convert a MUFA (trans-11 18:1) to cis-9, trans-11 CLA. The DIX has previously been used to reflect the amount of $\Delta^{9}$-desaturase activity in the mammary gland, which has been correlated positively with $\Delta^{9}$-desaturase mRNA levels (Singh et al., 2004). One of the fatty acids that $\Delta^{9}$-desaturase enzyme converts is vaccenic acid (trans-11 18:1) into cis-9, trans-11 CLA, which is the predominant CLA found in the rumen (Bauman et al., 2003). The benefits of cis-9, trans-11 CLA and MUFA on human health have led to widespread interest in increasing their concentration in the human diet. By evaluating the $\Delta^{9}$-desaturase enzyme activity in various tissues, a way may be found to increase the concentrations of cis-9, trans-11 CLA and MUFA within the meat and milk for human consumption. The DIX index has been defined previously using the following equation: (product of $\Delta^{9}$-desaturase)/(product of $\Delta^{9}$-desaturase + substrate of $\Delta^{9}$-desaturase); Kelsey et al., 2003. Kelsey et al. (2003) calculated a DIX for 4 pairs of fatty acids that represented products and substrates for $\Delta^{9}$ - 
Table 8. Least squares means and pooled SE for total fatty acids ( $\mathrm{g} / 100 \mathrm{~g}$ of freeze-dried tissues) and different fatty acid percentages (g/ $100 \mathrm{~g}$ of fatty acids) in muscle, subcutaneous adipose, and internal adipose tissue at d 17 after a synchronized estrus (d 0) in lactating cyclic (C) cows fed a control diet, pregnant (P) cows fed a control diet, and cyclic cows fed a fish oil-enriched lipid (FO) diet and injected with or without bST on $\mathrm{d} 0$ and 11

\begin{tabular}{|c|c|c|c|c|c|c|c|c|c|c|c|c|c|}
\hline 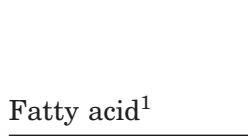 & \multicolumn{6}{|c|}{ Treatment $^{2}$} & $\mathrm{SE}$ & \multicolumn{3}{|c|}{ Cyclic contrasts $^{3}$} & \multicolumn{3}{|c|}{ Pregnant contrasts ${ }^{3}$} \\
\hline Total fatty acids & 8.7 & 6.4 & 5.7 & 6.4 & 9.7 & 7.1 & 2.2 & NS & NS & NS & NS & NS & NS \\
\hline SFA & 43.39 & 41.73 & 45.53 & 46.69 & 45.94 & 46.54 & 1.71 & $*$ & NS & NS & $*$ & NS & NS \\
\hline UNSFA & 56.62 & 58.26 & 54.47 & 53.30 & 54.06 & 53.45 & 1.69 & * & NS & NS & * & NS & NS \\
\hline MUFA & 39.73 & 37.77 & 33.17 & 33.20 & 38.29 & 38.88 & 3.38 & NS & NS & NS & NS & NS & NS \\
\hline DIX & 0.17 & 0.22 & 0.11 & 0.10 & 0.13 & 0.15 & 0.02 & $* *$ & NS & NS & $* *$ & NS & NS \\
\hline \multicolumn{14}{|c|}{ Subcutaneous adipose } \\
\hline Total fatty acids & 74.4 & 76.7 & 75.0 & 67.9 & 76.3 & 72.9 & 3.5 & NS & NS & NS & NS & NS & NS \\
\hline SFA & 48.79 & 55.31 & 58.17 & 61.49 & 58.89 & 47.50 & 2.82 & $* *$ & $\dagger$ & NS & NS & NS & $* *$ \\
\hline UNSFA & 51.21 & 44.69 & 41.83 & 38.51 & 41.11 & 52.50 & 2.81 & ** & $\dagger$ & NS & NS & NS & ** \\
\hline MUFA & 47.96 & 42.05 & 38.07 & 35.63 & 38.71 & 49.82 & 2.69 & $* *$ & NS & NS & NS & NS & $* *$ \\
\hline PUFA & 3.25 & 2.63 & 3.76 & 2.88 & 2.40 & 2.68 & 0.37 & NS & $\dagger$ & NS & NS & NS & NS \\
\hline SFA & 63.73 & 63.06 & 64.60 & 66.10 & 64.29 & 65.87 & 2.06 & NS & NS & NS & NS & NS & NS \\
\hline UNSFA & 36.27 & 36.93 & 35.41 & 33.88 & 35.72 & 34.14 & 2.06 & NS & NS & NS & NS & NS & NS \\
\hline MUFA & 33.12 & 33.80 & 32.37 & 30.90 & 32.97 & 31.71 & 2.20 & NS & NS & NS & NS & NS & NS \\
\hline PUFA & 3.14 & 3.13 & 3.04 & 2.98 & 2.75 & 2.43 & 0.31 & NS & NS & NS & $\dagger$ & NS & NS \\
\hline n6:n3 & 11.67 & 9.99 & 11.95 & 12.23 & 9.08 & 13.63 & 1.40 & NS & NS & NS & NS & NS & $*$ \\
\hline DIX & 0.06 & 0.10 & 0.06 & 0.04 & 0.05 & 0.04 & 0.01 & $* *$ & NS & $* *$ & $* *$ & $\dagger$ & * \\
\hline
\end{tabular}

${ }^{1} \mathrm{SFA}=$ Saturated fatty acids, UNSFA = unsaturated fatty acids, MUFA = monounsaturated fatty acids, PUFA = polyunsaturated fatty acids, DIX = desaturase index $(\mathrm{C} 14: 1) /(\mathrm{C} 14: 0+\mathrm{C} 14: 1)), \mathrm{n} 6: \mathrm{n} 3=(\mathrm{C} 18: 2+\mathrm{C} 20: 4) /(\mathrm{C} 18: 3+\mathrm{C} 20: 5+\mathrm{C} 20: 6)$.

${ }^{2}$ No bST-C = Cyclic cows not injected with bST $(\mathrm{n}=5)$; bST-C = cyclic cows injected with bST $(\mathrm{n}=5)$; no bST-FO-C = cyclic cows not injected with bST and fed a fish oil-enriched supplement $(\mathrm{n}=5)$; bST-FO-C = cyclic cows injected with bST and fed a fish oil-enriched supplement $(\mathrm{n}=4)$; no bST-P = pregnant cows not injected with bST $(\mathrm{n}=4)$; bST-P = pregnant cows injected with bST $(\mathrm{n}=5)$.

${ }^{3}$ Contrasts for cyclic cows were: FO = (no bST-C + bST-C) vs. (no bST-FO-C + bST-FO-C), bST = (no bST-C + no bST-FO-C) vs. bST-C + bST-FO-C), and bST $\times$ FO interaction $=($ no bST-C + bST FO-C $)$ vs. $($ bST-C + no bST-FO-C $)$. Contrasts for pregnant cows were: $\mathrm{P}=($ no bST$\mathrm{C}+\mathrm{bST}-\mathrm{C})$ vs. $($ no bST-P + bST-P), bST $=($ no bST-C + no bST-P) vs. $(\mathrm{bST}-\mathrm{C}+\mathrm{bST}-\mathrm{P})$, and bST $\times \mathrm{P}$ interaction $=($ no bST-C $+\mathrm{bST}-\mathrm{P})$ vs. (bST-C + no bST-P).

$\dagger P \leq 0.10 ; * P \leq 0.05$; ** $P \leq 0.01$; NS $=$ nonsignificant.

desaturase and reported that all $4 \Delta^{9}$-desaturase indexes were highly correlated. The lower the DIX, the less active the $\Delta^{9}$-desaturase is thought to be. Feeding FO decreased DIX in the muscle and s.c. adipose tissue with a concurrent increase in SFA percentage and a decrease in UNSFA percentage. In addition, the FO diet decreased DIX in the endometrium. When bST was injected into cyclic control-fed cows, the DIX increased in the mammary and internal adipose tissues whereas bST injected into FO-fed cows resulted in a decreased DIX with no difference in the proportions of SFA and UNSFA. This illustrates that bST injections can influence the effects of $\mathrm{FO}$ on the $\Delta^{9}$-desaturase enzyme in some bovine tissues. Previous studies have shown that insulin can increase $\Delta^{9}$-desaturase mRNA expression (Daniel et al., 2004). In the present study, FO reduced insulin concentrations in plasma with no additive effects of bST. In addition, cyclic control-fed cows given
bST had reduced insulin concentrations (Bilby et al., 2006b). It seems that FO and bST effects on the $\Delta^{9}$ desaturase enzyme may not be acting through insulin but possibly through direct regulation of enzyme expression. In rodents, dietary PUFA have been shown to directly repress a variety of genes at the level of transcription, including stearoyl CoA desaturase (Sampath and Ntambi, 2005).

Cis-9, trans-11 CLA was increased in the milk fat by feeding the FO-enriched lipid, but decreased in the muscle and s.c. adipose tissue. In addition, trans-9, trans-11 CLA was increased slightly in mammary tissue in FO-fed cows and decreased in s.c. fat in FOfed cows not injected with bST compared with cyclic control-fed cows. This increase in mammary tissue CLA might be due not only to modified gene expression and enzymatic protein synthesis but also to regulation of enzyme activity because DIX was decreased in the 
Table 9. Least squares means and pooled SE for the subcutaneous adipose tissue fatty acid profile (\% of total fatty acids; g/100 g of fatty acids) at d 17 after a synchronized estrus (d 0) in lactating cyclic $(\mathrm{C})$ cows fed a control diet, pregnant (P) cows fed a control diet, and cyclic cows fed a fish oil-enriched lipid (FO) diet and injected with or without bST on d 0 and 11

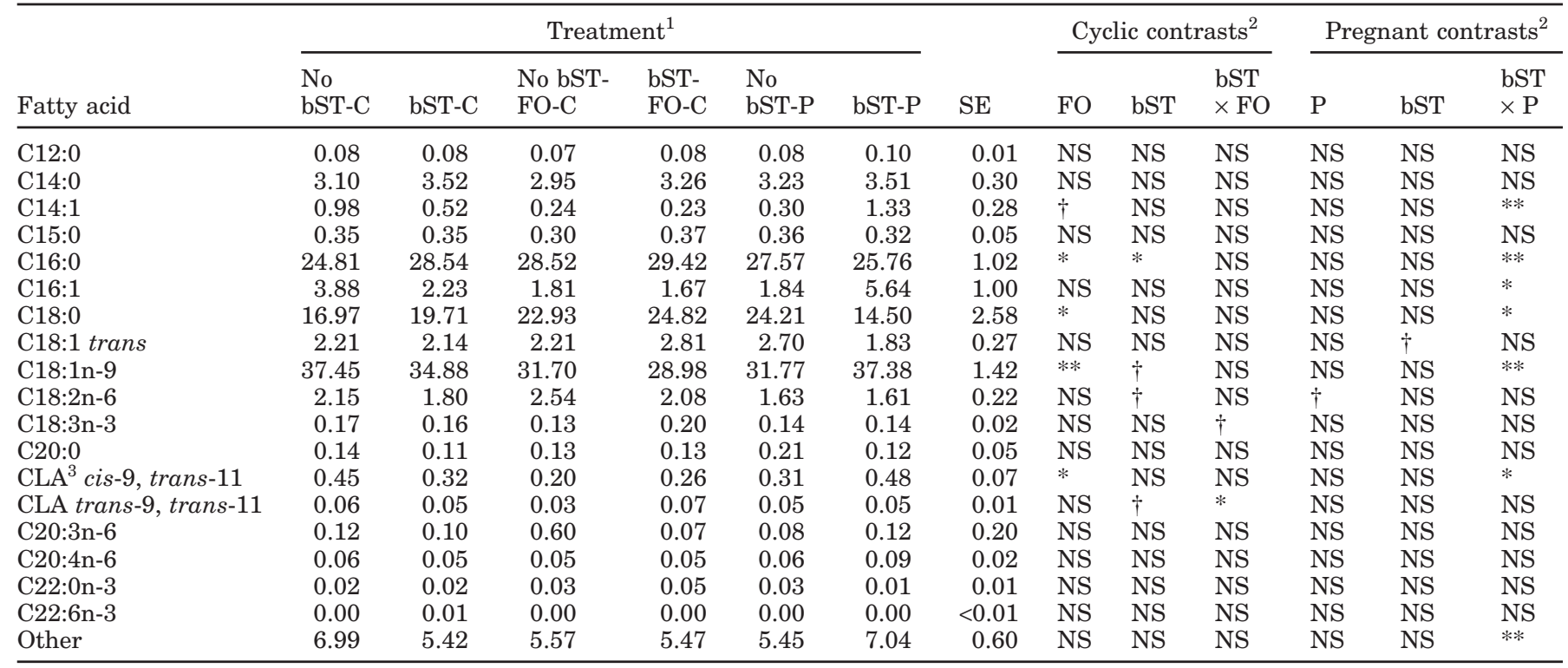

${ }^{1}$ No bST-C = Cyclic cows not injected with bST $(\mathrm{n}=5)$; bST-C = cyclic cows injected with bST $(\mathrm{n}=5)$; no bST-FO-C = cyclic cows not injected with bST and fed a fish oil-enriched supplement $(\mathrm{n}=5)$; bST-FO-C = cyclic cows injected with bST and fed a fish oil-enriched supplement $(\mathrm{n}=4)$; no bST-P = pregnant cows not injected with bST $(\mathrm{n}=4)$; bST-P = pregnant cows injected with bST $(\mathrm{n}=5)$.

${ }^{2}$ Contrasts for cyclic cows were: FO = (no bST-C + bST-C) vs. (no bST-FO-C + bST-FO-C), bST = (no bST-C + no bST-FO-C) vs. bST-C + bST-FO-C), and bST $\times$ FO interaction $=($ no bST-C + bST FO-C $)$ vs. $($ bST-C + no bST-FO-C). Contrasts for pregnant cows were: $\mathrm{P}=($ no bST$\mathrm{C}+\mathrm{bST}-\mathrm{C})$ vs. $($ no bST-P + bST-P), bST $=($ no bST-C + no bST-P $)$ vs. $($ bST-C + bST-P $)$, and bST $\times$ P interaction $=($ no bST-C + bST-P) vs (bST-C + no bST-P).

${ }^{3} \mathrm{CLA}=$ Conjugated linoleic acid.

$\dagger P \leq 0.10 ; * P \leq 0.05 ; * * P \leq 0.01 ; \mathrm{NS}=$ nonsignificant.

mammary gland tissue. Madron et al. (2002) found greater proportions of cis-9, trans-11 CLA in the i.m., intermuscular, and s.c. fat in crossbred Angus steers fed diets containing 12.7 to $25.6 \%$ extruded full-fat soybeans. Griinari and Bauman (1999) concluded that a relatively small proportion of cis-9, trans-11 CLA formed in the rumen escapes and is available for deposition in the muscles. Therefore, conversion of C18:2 to cis-9, trans-11 CLA by ruminal microorganisms does not seem to be the major source of cis-9, trans-11 CLA in meat.

Increases in milk yield of dairy cows treated with $\mathrm{bST}$ are the result of coordinated metabolic adaptations in various tissues. Overall effects of bST are to enhance growth and (or) lactation by coordinating nutrient utilization in a manner that supports enhanced performance (Etherton and Bauman, 1998). Treatment with bST affects both lipogensis and lipolysis, and this may be via the actions of IGF-I, insulin, or directly by GH (Etherton and Bauman, 1998). In the rat, GH treatment increased fatty acid synthase, stearoyl-CoA desaturase, and sterol regulatory element-binding protein $\mathrm{c}$ in the liver (Frick et al., 2002). When insulin and GH treatment were used in combination, effects were not addi- tive; instead, insulin blunted the effects of GH on expression of these genes. In contrast to the liver, adipose tissue gene expression was not influenced by GH. This could explain the interacting effects of bST injections with FO feeding seen in this experiment because FO reduced insulin concentrations in plasma and reduced the plasma IGF-I response to bST (Bilby et al., 2006b).

In the present study, bST reduced the amount of PUFA in the endometrium in cyclic cows and reduced PUFA in the mammary tissue and milk fat in pregnant cows. Injections of bST increased conceptus sizes and secretions (Bilby et al., 2006b) that may be the cause for the $b S T \times$ pregnancy interactions on fatty acid distributions in the endometrial tissue.

\section{CONCLUSIONS}

Dietary supplementation of a FO-enriched lipid, bST treatment, and early pregnancy can have altering effects on fatty acid proportions and distribution in reproductive and other tissues such as adipose, muscle, liver, and mammary gland. Feeding FO altered the endometrium by partially replacing C20:4 with $\mathrm{C} 20: 5$ and C22:6, which may decrease luteolytic pulsatile secretion 
Table 10. Least squares means and pooled SE for internal adipose tissue fatty acid profile (\% of total fatty acids; g/100 g of fatty acids) at d 17 after a synchronized estrus (d 0) in lactating cyclic (C) cows fed a control diet, pregnant (P) cows fed a control diet, and cyclic cows fed a fish oil-enriched lipid (FO) diet and injected with or without bST on d 0 and 11

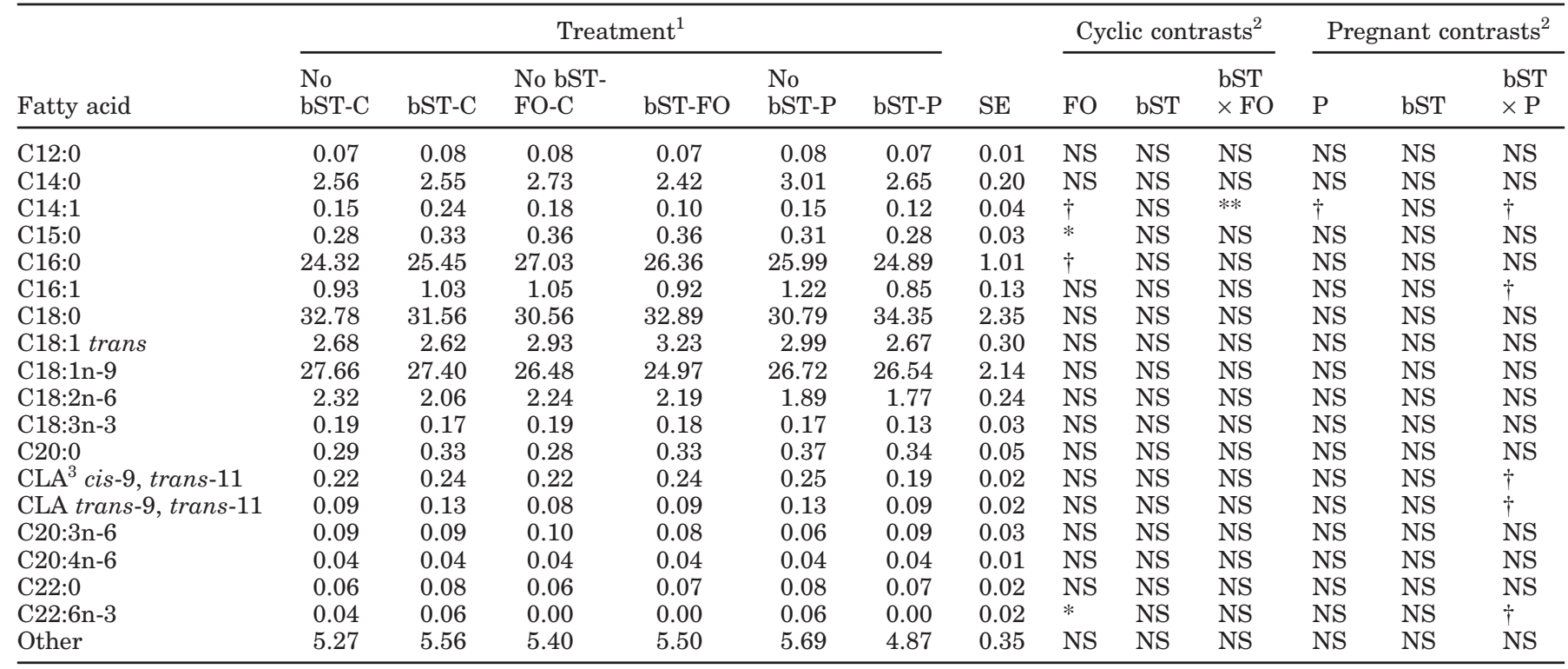

${ }^{1}$ No bST-C = Cyclic cows not injected with bST $(\mathrm{n}=5)$; bST-C = cyclic cows injected with bST $(\mathrm{n}=5)$; no bST-FO-C = cyclic cows not injected with bST and fed a fish oil-enriched supplement $(\mathrm{n}=5)$; bST-FO-C = cyclic cows injected with bST and fed a fish oil-enriched supplement $(\mathrm{n}=4)$; no bST-P = pregnant cows not injected with bST $(\mathrm{n}=4)$; bST-P = pregnant cows injected with bST $(\mathrm{n}=5)$.

${ }^{2}$ Contrasts for cyclic cows were: FO = (no bST-C + bST-C) vs. (no bST-FO-C + bST-FO-C), bST = (no bST-C + no bST-FO-C) vs. bST-C + bST-FO-C), and bST $\times$ FO interaction $=($ no bST-C + bST FO-C $)$ vs. $($ bST-C + no bST-FO-C $)$. Contrasts for pregnant cows were: $\mathrm{P}=($ no bST$\mathrm{C}+\mathrm{bST}-\mathrm{C})$ vs. $($ no bST-P + bST-P), bST $=($ no bST-C + no bST-P) vs. $($ bST-C + bST-P), and bST $\times$ P interaction $=($ no bST-C + bST-P) vs. (bST-C + no bST-P).

${ }^{3} \mathrm{CLA}=$ Conjugated linoleic acid.

$\dagger P \leq 0.10 ; * P \leq 0.05 ; * * P \leq 0.01 ; \mathrm{NS}=$ nonsignificant.

of $\mathrm{PGF}_{2 \alpha}$. Feeding $\mathrm{FO}$ also reduced the n-6:n-3 ratio that may improve immune function. Cows fed FO also had increased cis-9, trans-11 CLA concentrations in the milk fat that may provide a more nutritional product for consumers.

\section{ACKNOWLEDGMENTS}

Authors thank the staff of the University of Florida Dairy Research Unit for assistance in feeding and managing the experimental cows. Appreciation is extended to Larry Eubanks and the staff of the University of Florida Meats Laboratory for timely and careful sacrifice of experimental cows. This journal article was supported by the Florida Agricultural Experiment Station. Financial support also was received by the NRI Competitive Grant Program-USDA, grant no. 98-35203-6367.

\section{REFERENCES}

Abayasekara, D. R. E., and D. C. Wathes. 1999. Effects of altering dietary fatty acid composition on prostaglandin synthesis and fertility. Prostaglandins Leukot. Essent. Fatty Acids 61:275-287. Andrae, J. G., S. K. Duckett, C. W. Hunt, G. T. Pritchard, and F. N. Owen. 2001. Effects of feeding high-oil corn to beef steers on carcass characteristics and meat quality. J. Anim. Sci. 79:582588.

Bauman, D. E., B. A. Corl, L. H. Baumgard, and J. M. Griinari. 2001. Conjugated linoleic acid (CLA) and the dairy cow. Pages 221-250 in Recent Advances in Animal Nutrition. P. C. Garnsworthy and J. Wiseman, ed. Nottingham Univ. Press, Nottingham, UK.

Bauman, D. E., B. A. Corl, and D. G. Peterson. 2003. The biology of conjugated linoleic acids in ruminants. Pages 146-173 in Advances in Conjugated Linoleic Acid Research. Volume 2. J.-L. Sebedio, W. W. Christie, and R. O. Adlof, ed., AOCS Press, Champaign, IL.

Berger, J., and D. E. Moller. 2002. The mechanism of action of PPARs. Annu. Rev. Med. 53:409-435.

Bilby, T. R., A. Guzeloglu, L. A. MacLaren, C. R. Staples, and W. W. Thatcher. 2006a. Pregnancy, bovine somatotropin, and dietary n-3 fatty acids in lactating dairy cows: II. Gene expression related to maintenance of pregnancy. J. Dairy Sci. 89:3375-3385.

Bilby, T. R., A. Sozzi, M. M. Lopez, F. Silvestre, A. D. Ealy, C. R. Staples, and W. W. Thatcher. 2006b. Pregnancy, bovine somatotropin, and dietary n-3 fatty acids in lactating dairy cows: I. ovarian, conceptus, and growth hormone-insulin-like growth factor system responses. J. Dairy Sci. 89:3360-3374.

Burns, P. D., T. E. Engle, M. A. Harris, R. M. Enns, and J. C. Whittier. 2003. Effect of fish meal supplementation on plasma and endometrial fatty acid composition in nonlactating beef cows. J. Anim. Sci. 81:2840-2846.

Cooper, S. L., L. A. Sinclair, R. G. Wilkinson, K. G. Hallett, M. Enser, and J. D. Wood. 2004. Manipulation of the n-3 polyunsaturated fatty acid content of muscle and adipose tissue in lambs. J. Anim. Sci. 82:1461-1470. 
Corton, J. C., L. Q. Fan, S. Brown, S. P. Anderson, C. Bocos, R. C. Cattley, A. Mode, and J. A. Gustafsson. 1998. Down-regulation of cytochrome P450 2C family members and positive acute-phase response gene expression by peroxisome proliferator chemicals. Mol. Pharmacol. 54:463-473.

Daniel, Z. C., S. E. Richards, A. M. Salter, and P. J. Buttery. 2004. Insulin and dexamethasone regulate stearoyl-CoA desaturase mRNA levels and fatty acid synthesis in ovine adipose tissue explants. J. Anim. Sci. 82:231-237.

Donovan, D. C., D. J. Schingoethe, R. J. Baer, J. Ryali, A. R. Hippen, and S. T. Franklin. 2000. Influence of dietary fish oil on conjugated linoleic acid and other fatty acids in milk fat from lactating dairy cows. J. Dairy Sci. 83:2620-2628.

Etherton, T. D., and D. E. Bauman. 1998. Biology of somatotropin in growth and lactation of domestic animals. Physiol. Rev. 78:745-761.

Felton, E. E. D., and M. S. Kerley. 2004. Performance and carcass quality of steers fed different sources of dietary fat. J. Anim. Sci. 82:1794-1805

Frick, F., D. Linden, C. Ameen, S. Eden, A. Mode, and J. Oscarsson. 2002. Interaction between growth hormone and insulin in the regulation of lipoprotein metabolism in the rat. Am. J. Physiol. Endocrinol. Metab. 283:E1023-E1031.

Griinari, J. M., and D. E. Bauman. 1999. Biosynthesis of conjugated linoleic acid and its incorporation into meat and milk in ruminants. Chapter 13 in Advances in Conjugated Linoleic Acid Research. Vol. 1. M. P. Yurawecs, M. M. Mossoba, J. K. G. Kramer, M. W. Pariza, and G. J. Nelson, ed. AOCS Press, Champaign, IL.

Kelsey, J. A., B. A. Corl, R. J. Collier, and D. E. Bauman. 2003. The effect of breed, parity, and stage of lactation on conjugated linoleic acid (CLA) in milk fat from dairy cows. J. Dairy Sci. 86:2588-2597.

Khan, A. S., and J. P. Vanden Heuvel. 2003. Role of nuclear receptors in the regulation of gene expression by dietary fatty acids. J. Nutr. Biochem. 14:554-567.

Kramer, J. K., V. Fellner, M. E. Dugan, F. D. Sauer, M. M. Mossoba, and M. P. Yurawecz. 1997. Evaluating acid and base catalysts in the methylation of milk and rumen fatty acids with special emphasis on conjugated dienes and total trans fatty acids. Lipids 11:1219-1228.

Lim, H., R. A. Gupta, W. G. Ma, B. C. Paria, D. E. Moller, J. D. Morrow, R. N. Bubois, J. M. Trzaskos, and S. K. Dey. 1999. Cyclooxygenase-2-derived prostacyclin mediates embryo implantation in the mouse via PPAR $\delta$. Gene Dev. 13:1561-1574.

Madron, M. S., D. G. Peterson, D. A. Dwyer, B. A. Corl, L. H. Baumgard, D. H. Beerman, and D. E. Bauman. 2002. Effect of extruded full-fat soybeans on conjugated linoleic acid content of intramuscular, intermuscular, and subcutaneous fat in beef steers. J. Anim. Sci. 80:1135-1143.

Mattos, R, C. R. Staples, A. Arteche, M. C. Wiltbank, F. J. Diaz, T. C. Jenkins, and W. W. Thatcher. 2004. The effects of feeding fish oil on uterine secretion of $\mathrm{PGF}_{2 \alpha}$, milk composition, and metabolic status of periparturient Holstein cows. J. Dairy Sci. 87:921-932.

Rukkwamsuk, T., M. J. H. Geelen, T. A. M. Kruip, and T. Wensing. 2000. Interrelation of fatty acid composition in adipose tissue, serum, and liver of dairy cows during the development of fatty liver postpartum. J. Dairy Sci. 83:52-59.

Rukkwamsuk, T., T. A. M. Kruip, G. A. L. Meijer, and T. Wensing. 1999. Hepatic fatty acid composition in periparturient dairy cows with fatty liver induced by intake of a high energy diet in the dry period. J. Dairy Sci. 82:280-287.

Sampath, H., and J. M. Ntambi. 2005. Polyunsaturated fatty acid regulation of genes of lipid metabolism. Annu. Rev. Nutr 25:317-340.

Sewell, R. F., and L. R. McDowell. 1966. Essential fatty acid requirement of young swine. J. Nutr. 89:64-68.

Singh, K., D. G. Hartley, T. B. McFadden, and D. D. S. Mackenzie. 2004. Dietary fat regulates mammary stearoyl CoA desaturase expression and activity in lactating mice. J. Dairy Res. 71:1-6.

Thibault, C., D. Petitclerc, R. Spratt, M. Leonard, K. Sejrsen, and P. Lacasse. 2003. Effect of feeding prepuberal heifers with a high oil diet on mammary development and milk production. J. Dairy Sci. 86:2320-2326.

Tocher, D. R., M. J. Leaver, and P. A. Hodgson. 1998. Recent developments in the molecular biology and biochemistry of fatty acyl desaturases. Prog. Lipid Res. 37:73-117. 